\title{
IMPLEMENTASI CUSTOMER RELATIONSHIP MANAGEMENT(CRM) PADA TOKO ROTI GANDA BERBASIS WEB
}

\author{
Yosua Oliver Siallagan ${ }^{1}$, Naikson F. Saragih ${ }^{2}$, Jhoni Maslan Hutapea ${ }^{3}$ \\ Sistem Informasi, Fakultas Ilmu Komputer Universitas Methodist Indonesia \\ Jl.Hang Tuah No.8, Medan 20152, Sumatera Utara \\ 1yosuaoliver97@gmail.com, 2saragihnaikson@gmail.com,
}

\begin{abstract}
ASTRACT
Competition in the business world in the era of globalization is now getting stronger. For that a business requires a system that works efficiently and effectively. The Ganda Bakery is one of Pematang Siantar's special culinary delights which is well known among the people in the city and outside the city. Double Bakery is a legendary bakery that has existed since 1979 which is very crowded and in demand by people in the city and outside the city. Due to the large number of customers who come to the Double Bread Shop, so many new bakeries are trying to provide types of bread that resemble the menu in the Ganda Roti Shop, so that many new bakery businesses are opening to compete for customers at the Ganda Roti Shop. Therefore, by looking at the conditions and problems at the Ganda Bakery, it is necessary to have a media in the form of an online-based system to integrate ordering, marketing, and customer service that can manage the relationship between the company and its customers by creating applications with the CRM concept. In this study using the User Centered Design (UCD) method is a new paradigm in the development of webbased systems. The purpose of using this UCD method is to overcome the problem of the user's inability to use the system, and it is hoped that the user will be able to know the function of the system only in one use. The UCD method involves potential users in the early stages of development so that potential users can provide input regarding the ecommerce system interface. The final result in building e-commerce is expected to produce maximum appearance and functionality and have usability values. So that UCD is very suitable to be used in developing and building systems effectively and efficiently at the Double Bakery.
\end{abstract}

Keywords: Customer Relationship Management (CRM), E-Business, UMKM, UCD Method.

\section{PENDAHULUAN}

Persaingan dunia bisnis di era globalisasi kini semakin kuat. Untuk itu suatu usaha diperlukan sebuah sistem yang bekerja secara efisien dan efektif. Pada zaman teknologi yang sudah semakin canggih, pebisnis mengikut perkembangan dengan penerapan teknologi dan komunikasi yang semakin intensif dalam bebagai macam kalangan, baik itu pebisnis, pengusaha, industri dan kegiatan lainnya. Sehingga setiap usaha semakin berfikir untuk semakin berinovasi untuk bersaing dengan perusahaan lainnya dengan mengikuti teknologi yang ada pada zaman sekarang agar dapat mendekatkan diri kepada pelanggan dan meningkatkan loyalitas terhadap pelanggan.

Toko Roti Ganda merupakan salah satu kuliner khas Pematang Siantar yang sudah banyak dikenal dikalangan masyrakat dalam kota maupun luar kota. Toko Roti Ganda adalah Toko Roti legendaris yang sudah ada sejak tahun 1979 yang sangat ramai dan diminati oleh masyarakat dalam kota maupun luar kota. Toko Roti Ganda dikenal dengan roti tawar yang dioles dengan meses atau selai srikaya, selain itu juga tersedia roti manis yang berisi coklat, srikaya, seres, dan kelapa di dalamnya, ada juga tersedia roti tar, bolu, bika ambon, roti abon dan kue basah. Namun Toko Roti Ganda lebih dikenal dengan selai srikaya atau krim dengan seres. Dikarenakan selai srikaya dan krim seres banyak diminati oleh masyarakat, maka banyak juga pelanggan hanya membeli selai untuk dikirim keluar kota sebagai oleh-oleh atau buah tangan.
Dikarenakan banyaknya pelanggan yang datang ke Toko Roti Ganda, sehingga banyak toko roti baru yang berusaha menyediakan jenis-jenis roti yang menyerupai menu yang ada di Toko Roti Ganda, sehingga banyaknya usaha toko roti yang baru dibuka untuk bersaing untuk merebut pelanggan di Toko Roti Ganda. Terlepas dari upaya yang diberikan Toko Roti Ganda dalam memberikan pelayanan yang prima untuk meningkatkan loyalitas pelanggan dan dalam mendapatkan pelanggan baru ditemukan beberapa kendala pada proses bisnisnya, diantaranya ketika proses pembelian datang langsung ketempat akan menyita biaya dan waktu bagi pelanggan yang berada jauh dari lokasi Roti Ganda sedangkan jika pemesanan lewat telepon pelanggan tidak dapat melihat informasi mengenai produk yang ditawarkan dan stock yang ada.

CRM adalah suatu strategi bisnis yang menggunakan teknologi informasi untuk menghasilkan perusahaan yang berkompeten, terpercaya, dan terintegrasi dengan pelanggan membantu terpeliharanya dan meningkatkan hubungan relasi yang menguntungkan. Perusahaan harus memiliki CRM yaitu sebuah strategi bisnis yang dilakukan banyak perusahaan untuk menjaga hubungan baik pelanggan dengan perusahaan. Oleh karena itu, dengan melihat kondisi dan permasalahan pada Toko Roti Ganda maka diperlukan adanya media yang berupa sistem yang berbasis online untuk mengintegrasikan antara pemesanan, pemasaran, dan pelayanan konsumen yang dapat mengelolah hubungan antara perusahaan dengan pelanggan dengan membuat aplikasi dengan konsep CRM. 
Dimana dengan terjalinnya hubungan baik antar pelanggan dapat menumbuhkan loyalitas konsumen dalam melakukan transaksi. Mengelola CRM memang memerlukan waktu dengan mempelajari keinginan konsumen dari aktivitas - aktivitas transaksi yang telah terjadi, dari sisi tersebut muncul strategi yang dapat diterapkan seperti memberikan promo, discount, dan point pemesanan.

Dengan adanya CRM, maka ketertarikan pelanggan untuk belanja pada Toko Roti Ganda semakin meningkat. Business to Customer(B2C) adalah kegiatan e-business yang dilakukan secara langsung oleh perusahaan kepada konsumen perseorangan atau secara individu, di mana kegiatan transaksi umumnya menggunakan mekanisme toko online(online shop) sebagai store front yang berisikan katalog produk yang di tawarkan. Dengan transaksi penjualan langsung di internet dan pemesanan dapat langsung di lakukan oleh konsumen karena informasi mengenai detail info produk sudah tercantum pada halaman katalog produk. Penerapan B2C menawarkan banyak kelebihan baik kepada pelaku bisnis maupun kepada konsumen seperti kemudahan dalam melakukan transaksi, karena pelaku bisnis dan pelanggan tidak perlu berada pada suatu tempat yang sama, maka dari itu banyak pelaku bisnis yang tertarik menerapkan B2C.

Dengan kata lain, bisnis yang di lakukan berhubungan langsung dengan konsumen bukan perusahaan atau bisnislainnya. Untuk contohnya, misalkan seorang penjual sembako. Ketika menjual barang kepada konsumen perorangan maka bisnis yang dilakukan ialah B2C. Meskipun telepon, telemarketing dan transaksi penjualan mail order telah lama digunakan, namun peningkatan penjualan elektronika B2C telah secara signifikan dan secara eksponensial memperluas penjualan transnasional karena lebih sederhana, bentuk transaksi yang lebih murah, lebih cepat dan lebih nyaman.

User Centered Design(UCD) merupakan paradigm baru dalam pengembangan sistem berbasis web. UCD juga sering disebut sebagai human centered design. Tujuan penggunaan metode UCD ini adalah untuk mengatasi masalah ketidak mampuan pengguna dalam menggunakan sistem, dan diharapkan pengguna mampu mengetahui fungsi sistem hanya dalam sekali pakai. Metode UCD melibatkan calon pengguna pada tahap awal pengembangan sehingga calon pengguna dapat memberikan masukan mengenai antar muka sistem $e$ commerce. Hasil akhir dalam membangun e-commerce ini diharapkan menghasilkan tampilan dan fungsionalitas yang maksimal serta memiliki nilai usability. Sehingga UCD sangat cocok digunakan dalam pengembangan dan pembangunan sistem secara efektif dan efisien di Toko Roti Ganda. Kelebihan UCD sebagai best practices ialah dapat membantu untuk mengidentifikasi tantangan permasalahan dari awal agar solusi dapat ditemukan secepatnya. Dengan menggunakan UCD, dapat menghindari project yang gagal yang dilakukan oleh team. Penelitian ini dilakukan pada masa Pandemi Covid-
19. Oleh karena itu, metode ini sangat dibutuhkan dalam pemesanan atau pembelian produk di Toko Roti Ganda dengan efektif dan efisien tanpa harus datang ke Toko Roti Ganda.

\section{KAJIAN LITERATUR}

Customer Relationship Management(CRM)

CRM adalah sebuah strategi bisnis yang bersifat proaktif bertujuan untuk memupuk kesetiaan konsumen dan membuat mereka berjanji untuk menggunakan produk dan jasa perusahaan. Bila Kesetiaan terhadap suatu produk sudah terbentuk, akan timbul perilaku repeat buyer (pembelian berulang), dimana konsumen akan membeli produk perusahaan yang sama dalam jangka waktu panjang. Dengan situasi ini, sudah tentu perusahan dapat mempertahankan dan meningkatkan volume penjualannya secara terus menerus. Media untuk mewujudkan konsep CRM tersebut menggunakan Internet, dengan membangun suatu Website yang baru yang dilengkapi dengan database.

Customer Relationship Management adalah strategi atau filosofi yang memberikan visi bagi perusahaan untuk berurusan dengan pelanggan. Strategi manajemen hubungan pelanggan adalah memaksimalkan nilai hubungan. Dibutuhkan strategi dan proses holistik untuk keberhasilannya(Hia et al., 2018).

Kontak kepada customer pada banyak saluran akan dapat memaksimalkan pendapatan dan juga pelayanan.

Sistem CRM yang efisien setidaknya harus dapat memenuhi beberapa hal berikut:

a. Mengidentifikasi faktor-faktor penting untuk pelanggan.

b. Mempromosikan filosofi yang berorientasi pada pelanggan.

c. Mengadopsi langkah-langkah berbasis pelanggan.

d. Mengembangkan setiap proses dengan unsur melayani pelanggan.

e. Memberikan reward (dukungan) bagi pelanggan dengan penilaian baik.

f. Menangani keluhan pelanggan.

Berikut ini jenis-jenis CRM, sebagai berikut:

1. Strategic CRM

Strategic CRM berfokus pada pengembangan budaya bisnis customer-centric yang bertujuan untuk memenangkan dan mempertahankan konsumen. Budaya bisnis customer-centric dapat dicapai dengan menciptakan dan memberikan nilai yang lebih baik dibandingkan dengan kompetitor. Dalam budaya seperti costumer-centric, umumnya sumber daya yang ada akan ditempatkan pada posisi yang paling meningkatkan nilai konsumen, seperti menerapkan sistem reward untuk mendorong perilaku pegawai yang akan meningkatkan kepuasan pelanggan, selain itu, informasi mengenai konsumen juga dikumpulkan, dibagikan dan diterapkan dalam bisnis.

\section{Operational CRM}


Operasional CRM mengotomisasi dan mengembangkan proses bisnis cutomer facing dan customer supporting. Software aplikasi CRM memungkinkan fungsi-fungsi marketing, penjualan dan servis yang telah terotomosasi dan terintegrasi.

3. Analytical CRM

Analitis CRM (analytical CRM) fokus pada menangkap, menyimpan, mengekstraksi (extracting), mengintegrasi, memproses, menginterpretasi, menyebarkan, menggunakan dan melaporkan data yang berhubungan dengan konsumen (customerrelated data) untuk meningkatkan nilai konsumen dan perusahaan. Analitis CRM berpondasi pada informasi mengenai konsumen (customer-related).

4. Collaborative CRM

Kolaborasi CRM merupakan istilah yang digunakan untuk mendeskripsikan arah strategi dan taktik pada perusahaan yang umumnya terpisah dalam supply chain, dengan tujuan keuntungan yang lebih dalam identifikasi, atraksi, retention dan pengembangan pelanggan. Kolaborasi CRM menggunakan teknologi CRM untuk berkomunikasi dan bertransaksi diseluruh bagian organisasi.

Manfaat Customer Relationship Management adalah :

1. Mendorong loyalitas pelanggan: Aplikasi CRM memungkinkan perusahaan untuk memanfaatkan informasi dari semua titik kontak dengan pelanggan, baik melalui web, call center, atau melalui staf pelayanan di lapangan. Dengan adanya konsistensi dan kemudahan dalam mengakses dan menerima informasi, maka bagian pelayanan akan dapat memberikan layanan yang lebih baik lagi kepada pelanggan dengan memanfaatkan berbagai informasi penting mengenai pelanggan tersebut.

2. Mengurangi biaya: Dengan penerapan CRM, memungkinkan pelayanan terhadap pelanggan memiliki skema informasi yang spesifik dan terfokus, serta dengan menargetkan pelayanan pada pelanggan yang tepat pada saat yang tepat. Dengan demikian, biaya yang dikeluarkan akan menjadi tergunakan secara maksimal dan tidak terbuang percuma yang berujung pada pengurangan biaya.

3. 3.Meningkatkan efisiensi operasional: Kemudahan proses penjualan dan layanan akan dapat mengurangi resiko turunnya kualitas pelayanan dan mengurangi beban cash flow.

4. Peningkatan time to market: Penerapan CRM akan memungkinkan perusahaan mendapatkan informasi mengenai pelanggan seperti data tren pembelian oleh pelanggan yang dapat dimanfaatkan perusahaan dalam menentukan waktu yang tepat dalam memasarkan suatu produk.

5. Peningkatan pendapatan: Seperti yang telah disebutkan diatas, penerapan CRM yang tepat akan meningkatkan loyalitas pelanggan, mengurangi biaya, dan meningkatkan efisiensi operasional.

\section{UMKM}

UMKM adalah unit usaha produktif yang berdiri sendiri, yang dilakukan oleh orang perorangan atau badan usaha disemua sektor ekonomi. Pada prinsipnya pembedaan antara usaha mikro, usaha kecil, usaha menengah, usaha besar umumnya didasarkan pada nilai aset awal (tidak termasuk tanah dan bangunan, omset rata-rata per tahun, atau jumlah pekerja tetap.

Badan Pusat Statistik (BPS) mendefinisikan UMKM berdasarkan kuantitas tenaga kerja. Usaha kecil merupakan entitas usaha yang emiliki jumlah tenaga kerja 5 s.d 19 orang, sedangkan usaha menengah merupakan entitiams usaha yang memiliki tenaga kerja 20 s.d.99 orang. Menurut UU No 20 Tahun 2008 tentang Usaha Mikro, Kecil, dan Menengah (UMKM) adalah;

1. Usaha Mikro, yaitu usaha produktif milik orang perorangan atau badan usaha milik perorangan yang memenuhi kriteria yakni :

a. Memiliki kekayaan bersih paling banyak $\mathrm{Rp}$ 50.000.000 (lima puluh juta rupiah) tidak termasuk tanah dan bangunan tempat usaha

b. Memiliki hasil penjualan tahunan paling banyak $\mathrm{Rp}$ 300.000.000 (tiga ratus juta rupiah)

2. Usaha Kecil, yaitu usaha ekonomi produktif yang berdiri sendiri yang dilakukan oleh orang perorangan atau badan usaha yang bukan merupakan anak perusahaan atau bukan cabang perusahaan yang dimiliki, dikuasai atau menjadi bagian baik langsung maupun tidak langsung dari usaha menengah atau usaha besar dengan kriteria tertentu.

3. Usaha Menengah, yaitu usaha ekonomi produktif yang berdiri sendiri, yang dilakukan oleh orang perorangan atau badan usaha yang bukan merupakan anak perusahaan atau cabang perusahaan yang dimiliki, dikuasai, atau menjadi bagian baik langsung maupun tidak langsung dengan usaha kecil atau usaha besar.

\section{Pengertian UML}

UML(Unified Modelling Language) adalah bahasa pemodelan sistem atau perangkat lunak yang berparadigma berorientasi objek. Pengembangan UML dimulai dari kerjasama Grady Booch dan James Rumbaugh pada tahun 1994 untuk mengkombinasikan 2 metologi terkenal Booch dan OMG(Object Management Group). Notasi UML terutama diurutkan dari 3 notasi yang telah ada sebelumnya, yakni Grady Booch $\operatorname{OOD}($ Object Oriented Design), Jim Rumbough OMT(Object Modelling Technique) dan Ivar jacobson OOSE(Object Oriented Software Engineering) (Adi, 2018).

\section{Business To Customer(B2C)}

Dilihat dari jenis transaksinya, e-commerce dikelompokkan menjadi dua segmen yaitu, business to business e-commerce ( $\mathrm{B} 2 \mathrm{~B}$ e-commerce) dan business to consumer (B2C). B2B e-commerce adalah transaksi perdagangan melalui internet yang dilakukan oleh dua 
atau lebih perusahaan. Transaksi dagang tersebut sering disebut sebagai Enterprise Resource Planning (ERP) ataupun supply chain management. Sedangkan B2C $e$ commerce merupakan transaksi jual beli melalui internet antara penjual barang konsumsi dengan konsumen (end user) (Marhamahet al., 2018).

Model bisnis B2B dibagi menjadi 5 kategori sebagai berikut :

1. Pengembangan web

Bisnis dengan spesialiasasi dalam pengembangan web, desain web, SEO, pengembangan perangkat lunak, database, dan pembuatan situs menjadi yang paling banyak diburu saat ini. Tentu saja, itu menjadi peluang besar bagi perusahaan B2B.International Business Machine atau IBM adalah salah satu perusahaan B2B yang popular untuk kategori ini.

2. Perangkat lunak sebagai layanan ( $\mathrm{SaaS})$

Kategori B2B untuk kategori ini bekerja dengan menyediakan layanan atau platform perangkat lunak yang membantu aktivitas bisnis menjadi lebih mudah, mulai dari manajemen proyek, otomatisasi pemasaran, manajemen inventaris, sampai dengan pelacakan keuangan.

3. Pemasok kebutuhan bisnis

Era digital juga sudah merambah pada aktivitas pemasokan kebutuhan bisnis. Bahkan, saat ini perusahaan rela membayar perusahaan lain guna mendapatkan akses ke situs atau portal yang memiliki informasi tentang berbagai pasokan yang dibutuhkan oleh industri tertentu.

4. Perantara

Untuk kategori ini, bisnis B2B berperan sebagai situs perantara untuk memenuhi kebutuhan pasokan antara pemilik bisnis dan pemasok. Jika sudah bekerja sama dengan B2B, agen pembelian suatu perusahaandapat dengan mudah mengidentifikasi dan mengakses pasokan bahan baku, komponen, serta produk lainnya dari jarak jauh melalui situs $e$ procurement.

Banyak usaha B2C yang memanfaatkaninternet dan teknologi informasi dalam pemasaran produknya, seperti toko bukuGramedia danlain-lain. Implementasi konsep B2C biasanya melalui pembuatan website E-Commerce yangdigunakan untuk bertransaksi secara langsung dengan konsumen.

Dalam model bisnis B2C terbagi menjadi empat (4) kategori utama yaitu:

1. Penjualan Langsung

Pada model ini sering kita temui yaitu pengecer

barang secara online, menjual produknya secara langsung ke pelanggan melalui website.

Produsen produk menggunakan internet sebagai

katalog dan saluran

penjualan untuk menghilangkan perantara. Misal saja penjual hardware/software yang disediakan oleh Bhinneka (bukan merchant) yang menjangkau pembeli secara luas dan langsung.
2. Perantara Online

Bisnis yang dibantu oleh penyedia layanan perantara ini memberikan beberapa manfaat. Broker tersebut akan mendapatkan fee dari setiap penjualan mereka. Kita sebut saja olx, bukalapak, elevania, bhinneka (merchant) dan situs-situs lainnya yang memberikan jasa untuk menempatkan barang yang akan dijual kepada user.

3. Penjualan Berbasis Iklan

Penjualan berbais iklan disini adalah, suatu situs tertentu yang menjual layanan jasa berupa pemasangan iklan, dimana iklan tersebut dipasang pada situs yang sudah tinggi trafficnya, dengan semakin tinggi traffic kemudian iklan tersebut muncul dengan berupa banner/bentuk iklan dengan sedemikian rupa.

4. Penjualan Berbasis Biaya

Pada model ini dikenal juga dengan sistem subscriber, dimana Anda harus membayar pada suatu layanan atau jasa yang Anda gunakan. Kita sebut saja google cloud, layanan berbasis cloud yang disediakan oleh google ini memberikan banyak layanan komputasi online bagi pelanggan, mulai dari cloud storage, cloud vpn, big data dan aplikasi developer lainnya.

Klasifikasi E-Commerce diantaranya :

1. Business-To-Business (B2B)

B2B menyatakan penjualan produk atau jasa yang melibatkan beberapa perusahaan dilakukan dengan sistemotomasi. Umumnya perusahaan- perusahaan yang terlibat adalah pemasok, distributor, pabrik, toko, dan lain-lain.

2. Business-To-Consumer (B2C)

B2C melibatkan interaksi dan transaksiantara sebuah perusahaan penjual dan para konsumen.

3. Consumer-To-Consumer (C2C)

$\mathrm{C} 2 \mathrm{C}$ atau terkadang disebut person-to-person adalah model perdagangan yangterjadi antara konsumen dengan konsumen melalui internet.

4. Consumer-to-Business (C2B)

Beberapa situs telah berinisiasi untuk mendukung bisnis yang berbasiskan konsumen ke pebisnis (Marhamahet al., 2018).

\section{METODOLOGI PENELITIAN}

\section{Metode Pengumpulan Data}

Metode pengumpulan data terdiri dari pengamatan (observasi), wawancara interview), dokumentasi (documentation), dan kuisioner.

\section{Metode Perancangan Sistem}

Metodologi yang digunakan di dalam pengembangan sistem adalah metodologi UCD. UCD adalah sebuah filosofi perancangan yang menempatkan pengguna sebagai pusat dari sebuah proses pengembangan sistem. Kesulitan pengguna(end user) selama ini untuk membaca dan menerjemahkan dokumen- dokumen yang ada dalam setiap pengembangan dapat terbantu menggunakan 
metode UCD. Pendekatan UCD telah didukung berbagai teknik, metode, tools, prosedur dan proses yang membantu perancangan sistem interaktif yang lebih berpusat pada pengguna(Widhiarso et al., 2015).

\section{Analisi Sistem Yang Sedang Berjaan}

Dalam proses perancangan Penerapan E-Business pada Toko Roti Ganda berbasis web dengan pendekatan CRM (Customer Relationship Management) diperlukan penjelasan atau teori yang dapat mendukung dan menunjang keberhasilan dalam pembuatan sistem informasi tersebut serta untuk menjelaskan kepada user bagaimana fungsi dan manfaat dari penerapan E-Business pada Toko Roti Ganda berbasis web dengan pendekatan CRM. Berikut adalah gambar dari aliran sistem informasi yang sedang berjalan :

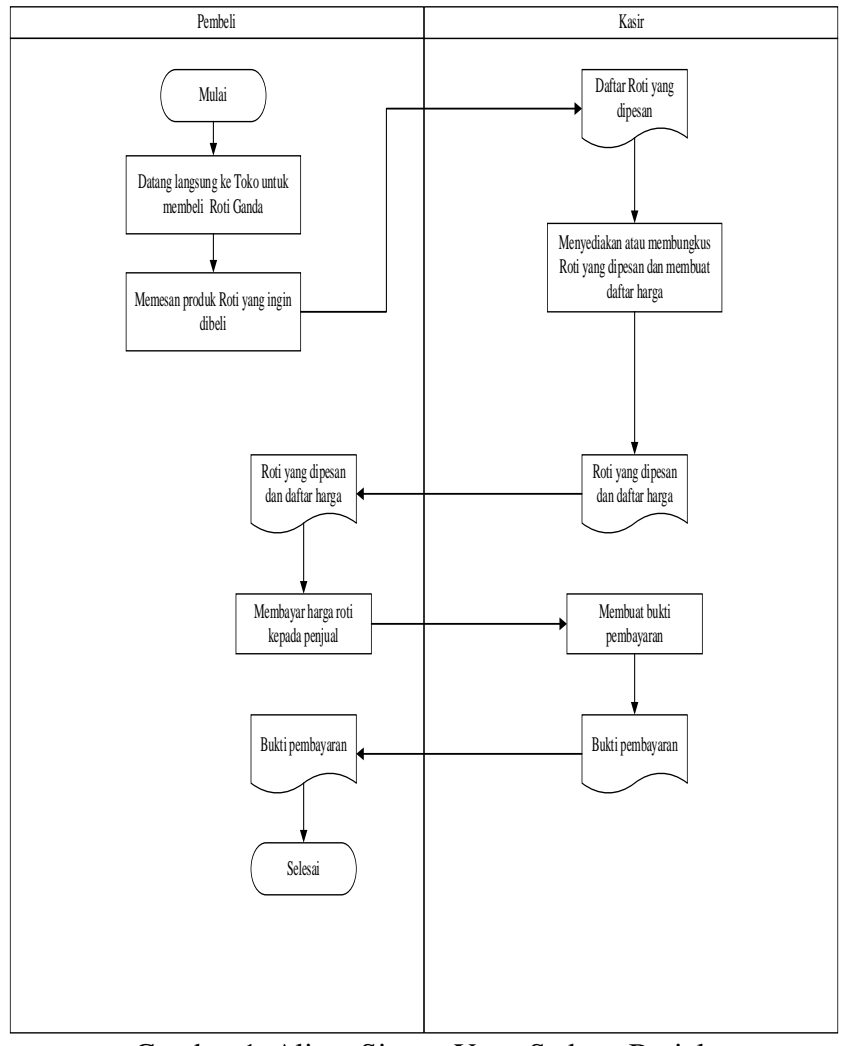

Gambar 1. Aliran Sistem Yang Sedang Berjalan

\section{Analisis Fungsional}

Analisis fungsional adalah tahapan yang menggambarkan fungsi-fungsi dari sistemyang akan dibangun.

\section{Use Case Diagram Administrator}

Use case diagram administrator akan menjelaskan kegiatan atau proses yang dapat dilakukan oleh aktor admin dalam sistem yang akan dibangun. Use case diagram administrator dapat dilihat seperti pada gambar 2

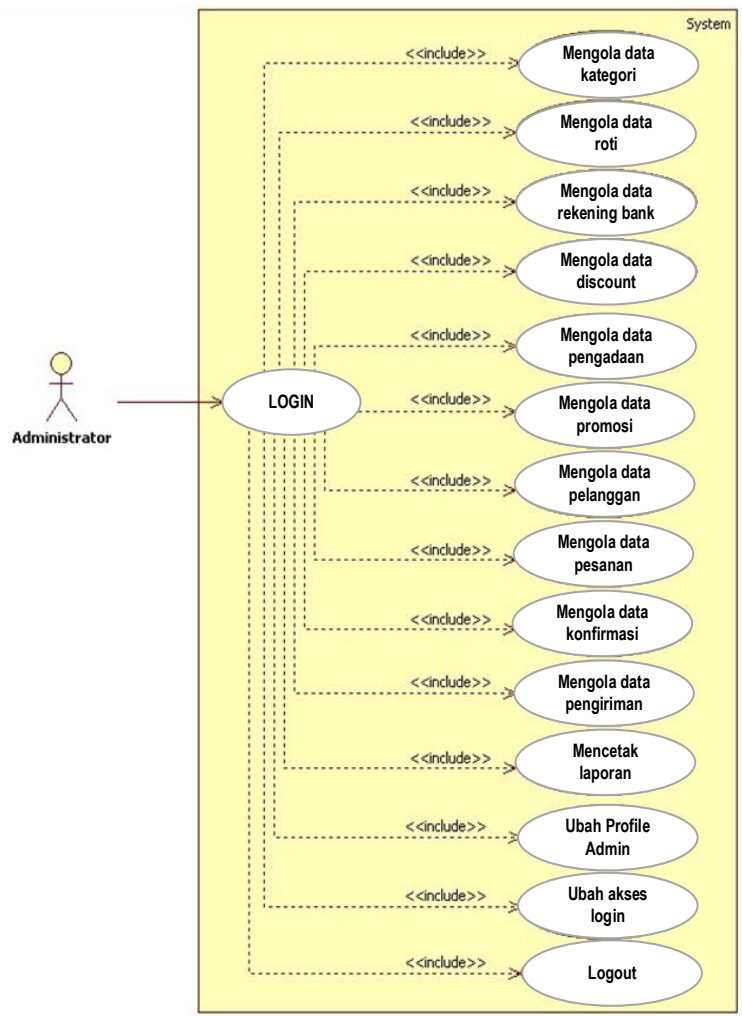

Gambar 2. Use Case Diagram Admin

\section{Use Case Diagram Pelanggan}

Use case diagram pelanggan berfungsi untuk menggambarkan kegiatan dan proses apa saja yang dapat dilakukan oleh pelanggan pada web yang akan dibangun. Use case diagram pelanggan dapat dilihat seperti pada gambar 3

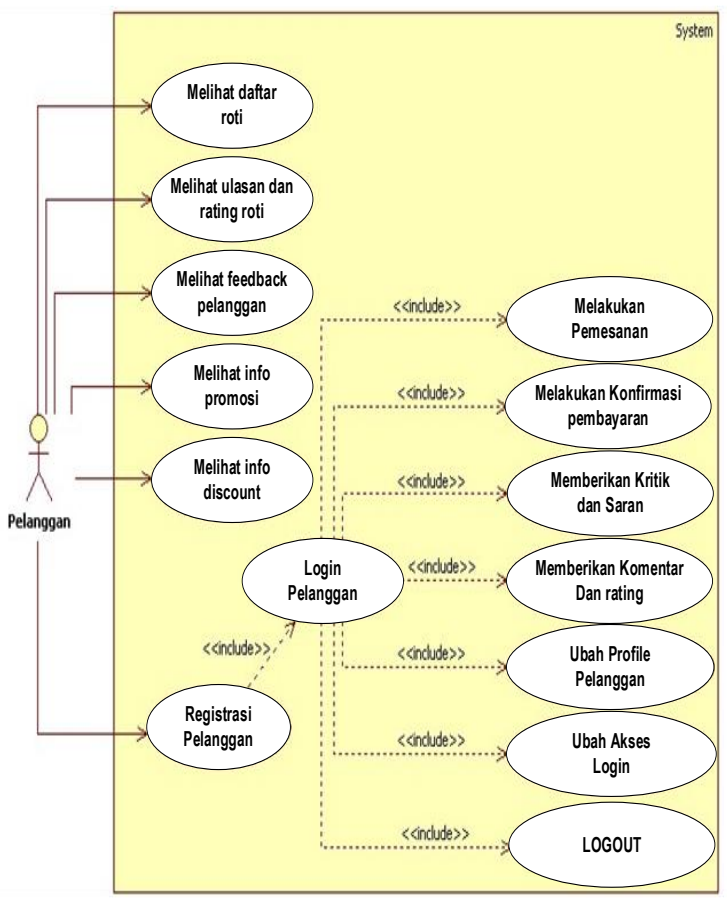

Gambar 3. Use Case Diagram Pelanggan 


\section{Activity Diagram Admin}

Activity diagram menggambarkan berbagai alir aktivitas dalam sistem yang akan dirancang, bagaimana masingmasing alir berawal dan bagaimana proses berakhir. Berikut adalah activity diagram pada sistem yang akan dibangun. Activity diagram login pelanggan menggambarkan aliran aktivitas antara pelanggan dan sistem pada saat melakukan login. Activity diagram login pelanggn dapat dilihat seperti pada gambar 4

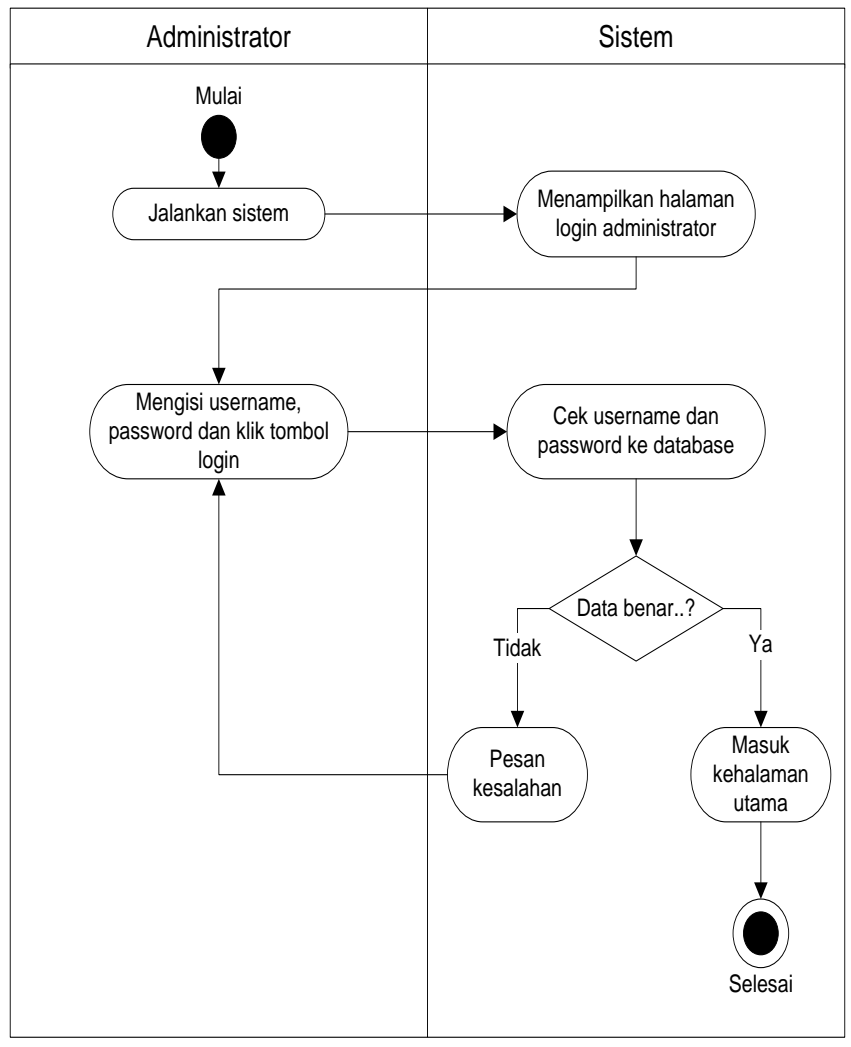

Gambar 4. Activity Diagram Admin

\section{HASIL DAN PEMBAHASAN}

Hasil dari Aplikasi pengolahan data penjualan Roti Ganda Dengan menggunakan CRM yang dibangun dapat dilihat pada gambar dibawah ini.

\section{Tampilan Halaman Utama User}

Halaman Utama berguna untuk melihat menu yang ada terdapat pada menu user, dan dapat melakukan login user. Adapun gambar form halaman utama user dapat dilihat pada gambar 4

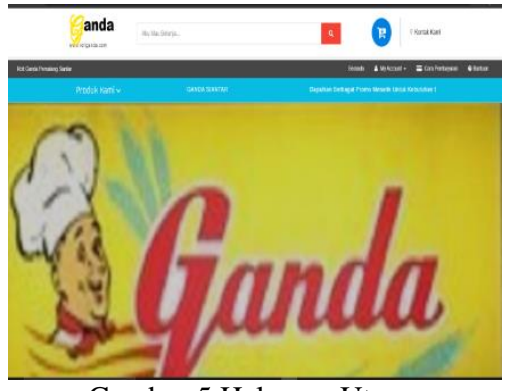

Gambar 5 Halaman Utama

2. Tampilan Form Status Order Pesanan

Form status order pesanan, dimana setiap konsumen melihat status order pesanan produk yang dilakukan oleh admin, adapun gambar form keranjang belanja dapat dilihat pada gambar 6

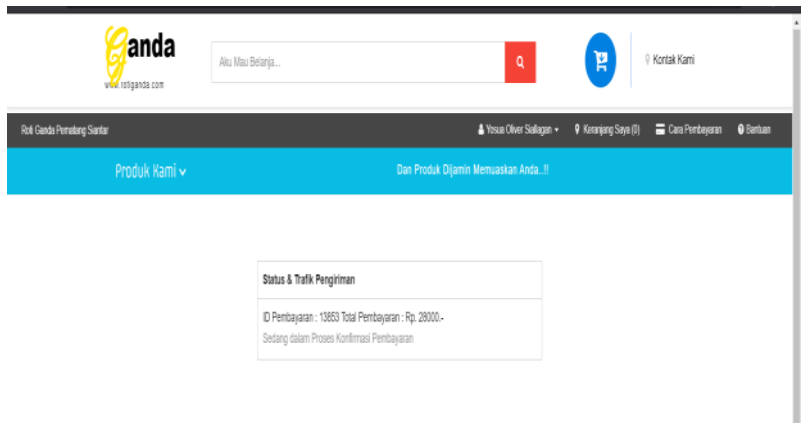

Gambar 6 Status Order Pesanan

3. Tampilan Form Keranjang Pesanan

Form keranjang pesanan dimana dilakukan setelah proses pemesanan produk yang dilakukan oleh konsumen dan akan disimpang di keranjang pesanan, adapun gambar keranjang pesanan dapat dilihat pada gambar 7
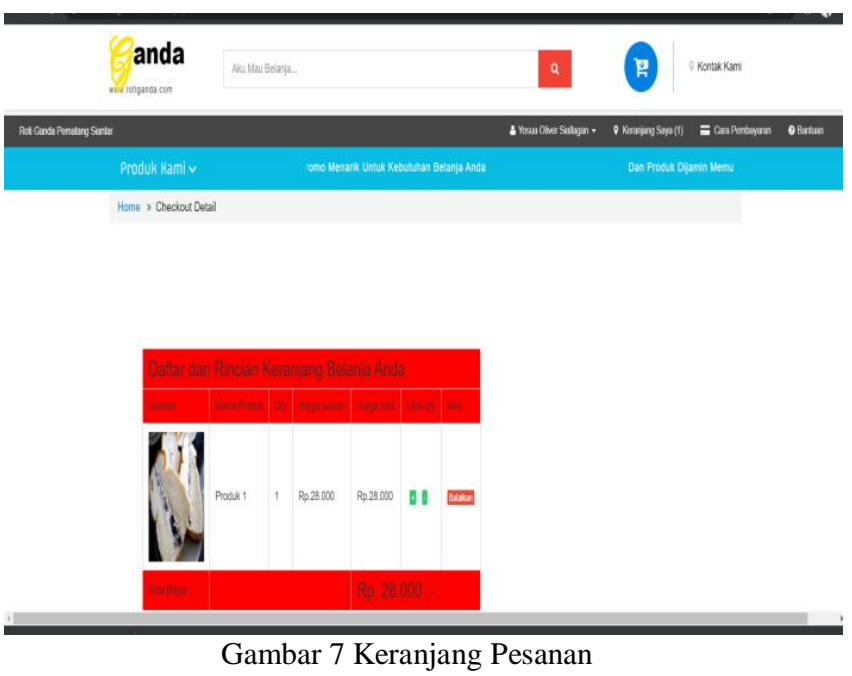

4. Tampilan Form Transaksi / Pembayaran

Form transaksi / pembayaran dimana dilakukan setelah proses pemesanan barang yang dilakukan oleh konsumen, adapun gambar transaksi / pembayaran dapat dilihat pada gambar 8 


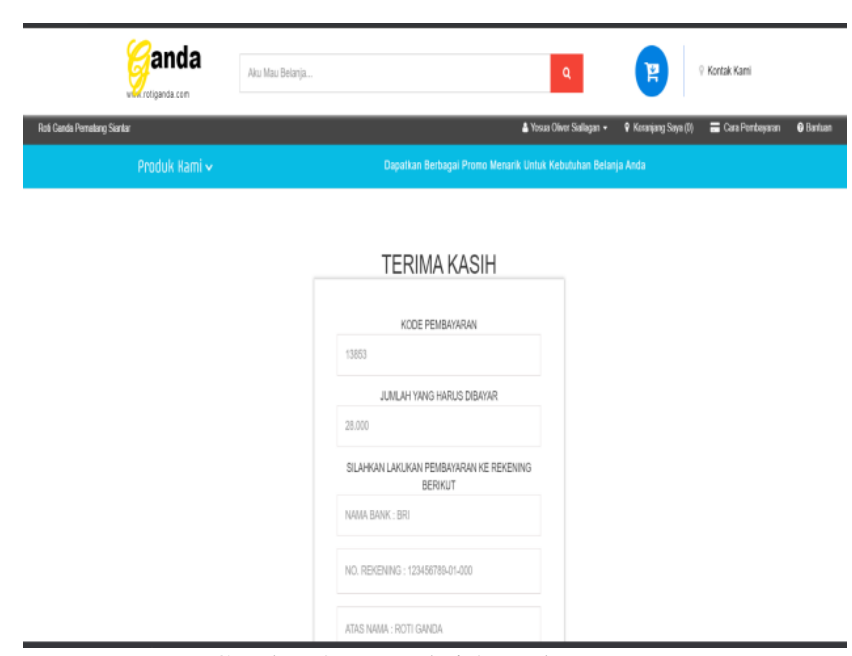

Gambar 8 Transaksi / Pembayaran

5. Tampilan Form Konfirmasi Pembayaran Form Konfirmasi Pembayaran dimana dilakukan setelah proses transaksi barang yang dilakukan oleh konsumen, adapun gambar form Konfirmasi Pembayaran dapat dilihat pada gambar 9

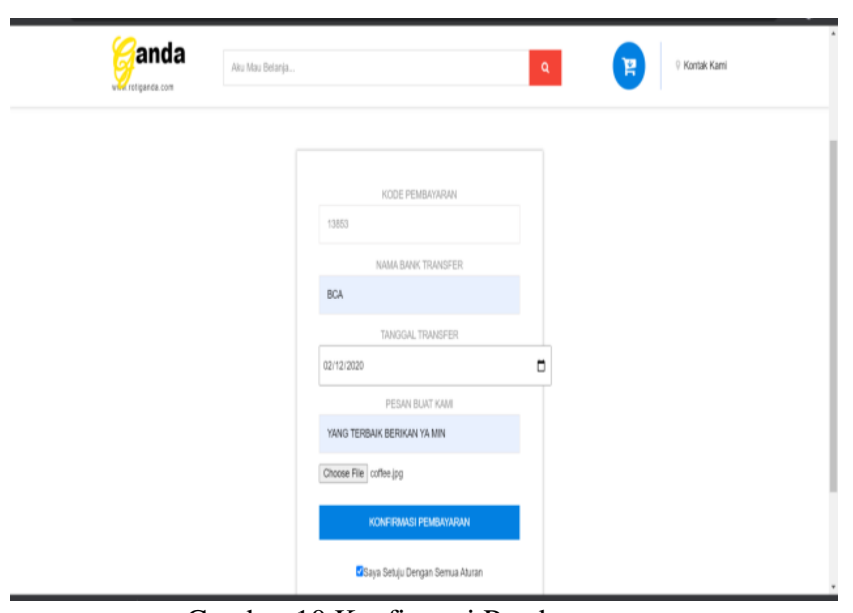

Gambar 10 Konfirmasi Pembayaran

\section{Hasil Pembahasan Tampilan Admin}

1. Tampilan Form Halaman Utama Admin Halaman Admin berfungsi setelah admin melakukan login dan dihalaman admin terdapat beberapa menu, adapun gambar form halaman utama admin dapat dilihat pada gambar 10

\section{ADMIN}

Q 1 Hod

Halaman Utama

thes

Data Pembayaran Terbaru

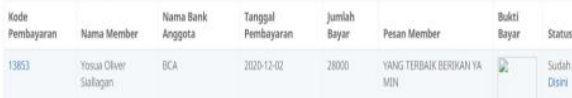

Data Member Terbaru

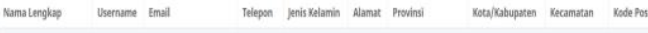

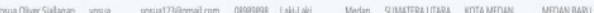

Data Keluhan Terbaru

Gambar 10 Halaman Utama Admin

2. Tampilan Input Promo
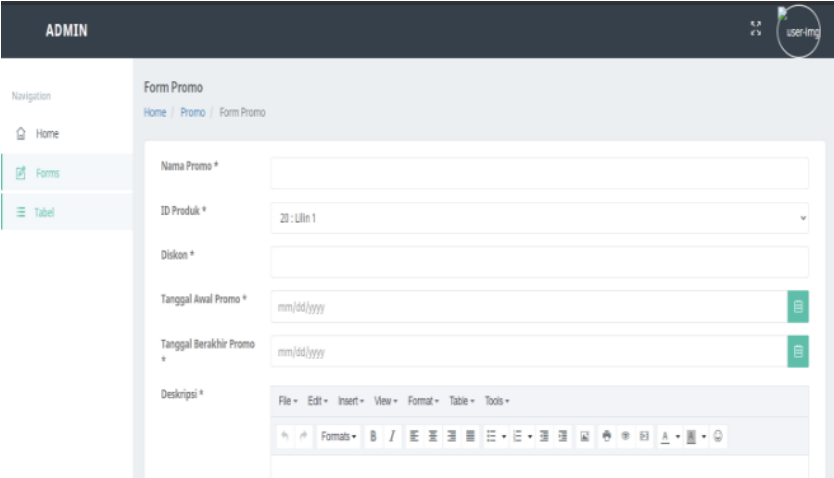

Gambar 11 Input Promo

3. Tampilan Validasi Transaksi

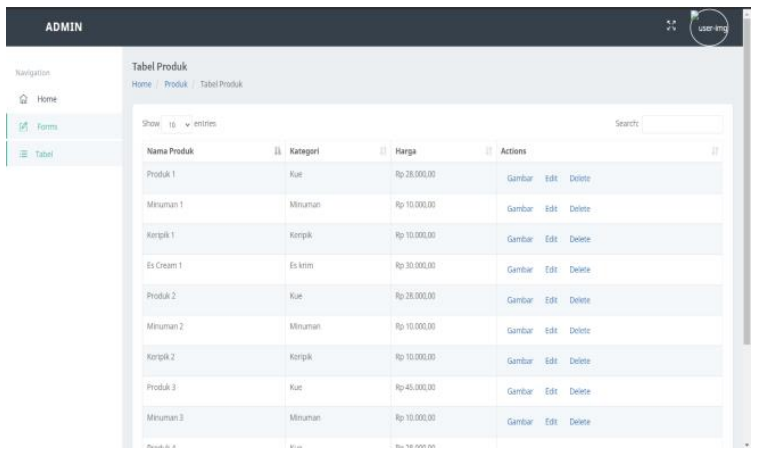

Gambar 12 Validasi Transaksi 


\section{Tampilan Tabel Keranjang}

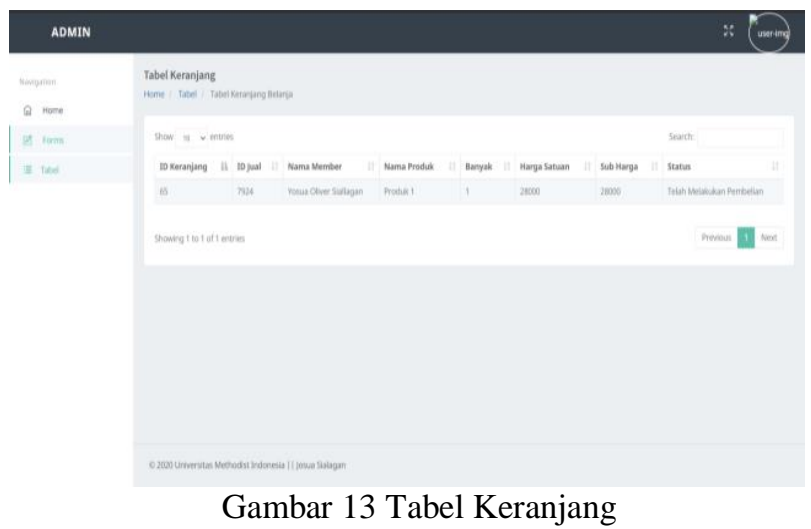

5. Tampilan Tabel Keluhan

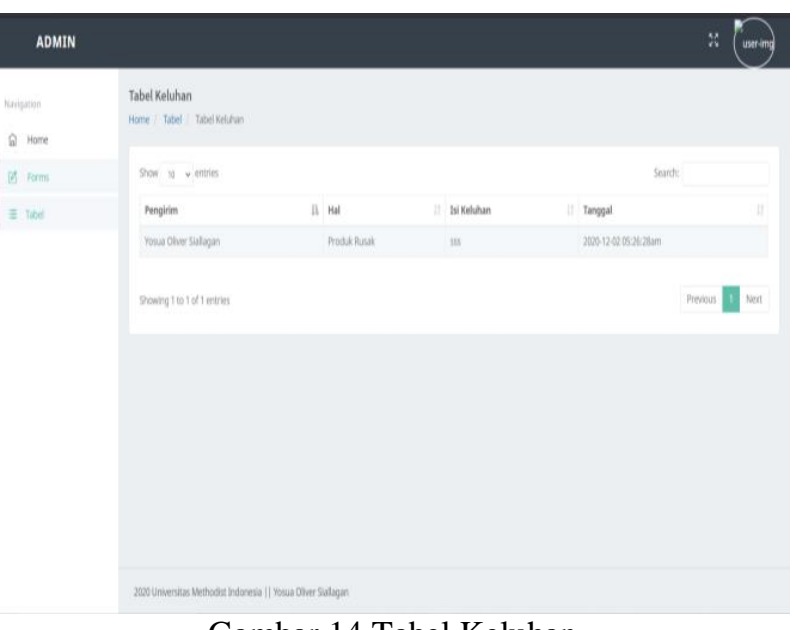

Gambar 14 Tabel Keluhan

\section{KESIMPULAN}

Berdasarkan pembahasan maka diberikan kesimpulan terhadap penerapan sistem penjualan Toko Roti Ganda Pematangsiantar yaitu Dengan adanya sistem informasi ini dapat membuat Toko Roti Ganda lebih dikenal dan mempermudah pengunjung dalam memperoleh data tentang data barang yang akan dijual serta CRM (Customer Relationship Management) yang di terapkan di Toko Roti Ganda meningkatkan penjualan hingga 28 $\%$. CRM yang diterapkan seperti adanya promosi produk, keranjang pemesanan produk, discount, dan transaksi, serta tersedianya fitur keluhan. Kemudian Toko Roti Ganda mendapatkan pelanggan baru dan mempertahankan pelanggan lama untuk tetap melakukan transaksi. Transaksi melalui ATM atau M-Banking untuk mempermudah pelanggan yang berada diluar Kota Pematangsiantar. Serta diharapkan dapat meningkatnya jumlah pemasaran produk karena sistem membantu proses penjualan kepada pelanggan yang berada di luar Pematang Siantar dalam perhari dengan CRM (Customer Relationship Management) seperti promosi produk, pemesanan produk melalui webstite. Ini menunjukkan adanya peningkatan omset penjualan.

\section{DAFTAR PUSTAKA}

[1]. Adi, N. (2018). Perancangan dan Implementasi Sistem Basis Data. Yogyakarta, 102.

[2]. Alamgir, M., \& Shamsuddoha, M. (2018). Customer Relationship Management (CRM) Succes Factor: An Exploratory Study". Journal of Departmen of Marketing, 4(6). https://doi.org/10.3969/j.issn.1006-8082.2011.06.013

[3]. Barnes, J. G. (2016). Secret of Customer Relationhip Management. Yogyakarta

[4]. Darmawan, A. (2015). Sistem Informasi Penjualan Berbasis Web. Jakarta, 3(1), 1-4.

[5]. Hia, H. H., Saragih, N. F., \& Larosa, F. G. N. (2018). Penerapan CRM pada Aplikasi Kantor Pelayanan Penyuluhan dan Konsultasi Perpajakan Kota Gunungsitoli (KP2KP). Medan, 3(2), 97-106. https://osf.io/preprints/inarxiv/8bmc4/

[6]. Marhamah, M., Hidayatuloh, S., \& Irawan, A. (2018). Sistem E-Commerce B2C Pada Pt. Harapan Sentosa Nusantara Jakarta Pusat. Studia Informatika: Jurnal Sistem Informasi, 9(2), 159-167.

[7]. Susanti, M. T., Larosa, F. G. N., \& Jaya, I. K. (2018). Perancangan Dan Pembuatan Website Marketplace Untuk Pemesanan Dan Penjualan Komoditas. Medan, 8, 20-21.

[8]. Widhiarso, W., Jessianti, \& Sutini. (2015). Metode UCD [User Centered Design] Untuk Rancangan Kios Informasi [Studi Kasus: Rumah Sakit Bersalin XYZ]. Algoritma, 3(3), 6-10. 